\title{
Blockade of surface bound TGF- $\beta$ abrogates Treg suppression of effector $T$ cell function within the tumor microenvironment
}

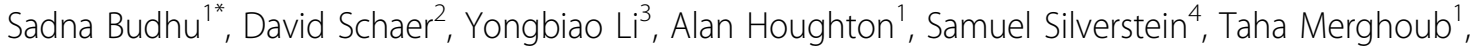 \\ Jedd D Wolchok'
}

From Society for Immunotherapy of Cancer 29th Annual Meeting

National Harbor, MD, USA. 6-9 November 2014

Regulatory $\mathrm{T}$ cells (Treg) play a role in suppression of anti-melanoma immunity; however, the exact mechanism is poorly understood. Through intravital two photon microcopy, we found that tumor-specific Pmel-1 effectors engage in cell-cell interactions with tumor resident Tregs. To determine if contact between Tregs and Teff hinders killing of tumor cells in vivo, we utilized ex-vivo threedimensional collagen-fibrin gel cultures of B16 melanoma cells. Collagen-fibrin gel cultures recapitulated the in vivo suppression, rendering the dissociated tumor resistant to killing by in vitro activated antigen specific $\mathrm{T}$ cells. In vivo depletion of Tregs in Foxp3-DTR mice prior to tumor excision reversed the suppression. In vivo modulation of Tregs by GITR ligation had a similar effect, reducing the number of intra-tumor Tregs leading to ex-vivo tumor killing. Using neutralizing antibodies, we found that blocking TGF- $\beta$ reversed the suppression. In addition, soluble factors from collagen-fibrin gel tumors do not inhibit killing suggesting that suppression is contact or proximity dependent. The CD8 $\mathrm{T}$ cells recovered from these gels exhibit a decrease in Granzyme B expression and an increase in expression of $\mathrm{T}$ cell exhaustion marker PD-1. These findings support the conclusion that intra-tumor contact with Tregs during the effector phase of the immune response is responsible for inhibiting anti-melanoma immunity in a TGF- $\beta$ dependent manner shedding light into novel ways to inhibit intratumoral Tregs.

This study was supported by Swim Across America; NIH grants R01CA56821, P01CA33049, and P01CA59350 (to J.W. and A.H.); D.S. and S.B. received support from the NIH/NCI Immunology Training GrantT32 CA09149-30.

IImmunology, Memorial Sloan Kettering Cancer Center, New York, NY, USA Full list of author information is available at the end of the article

\section{Authors' details}

${ }^{1}$ Immunology, Memorial Sloan Kettering Cancer Center, New York, NY, USA. ${ }^{2}$ Cancer Immunobiology, ImClone Systems, New York, NY, USA. ${ }^{3}$ Research Engineering, Memorial Sloan Kettering Cancer Center, New York, NY, USA. ${ }^{4}$ Physiology and Cellular Biophysics, Columbia University Medical Center, New York, NY, USA.

Published: 6 November 2014

\section{doi:10.1186/2051-1426-2-S3-P192}

Cite this article as: Budhu et al:: Blockade of surface bound TGF- $\beta$ abrogates Treg suppression of effector T cell function within the tumor microenvironment. Journal for ImmunoTherapy of Cancer 2014 2(Suppl 3): P192.

Submit your next manuscript to BioMed Central and take full advantage of:

- Convenient online submission

- Thorough peer review

- No space constraints or color figure charges

- Immediate publication on acceptance

- Inclusion in PubMed, CAS, Scopus and Google Scholar

- Research which is freely available for redistribution 